practised on arable and grazing land, especially in the semi-desert zone. At present, shelterwood has been planted on 4.1 million hectares, but this covers only half of the requirements, and shelterwood planting on a further 2.4 million hectares is thus planned for AD 1991 until AD 2005.

In the European USSR, there are almost 5,000 hectares of seed-tree crops, 70,000 hectares of land permanently set aside for seed-tree crops, and 12,000 hectares of genetic reserves, as well as important seed-improvement centres. There are 16 forest research centres, the most important being the 12 centres of the federal 'Lesproekt' group and the branches of the 'Soyouzguiproleskhoz' institute. A number of organizations set up by the Soviet Academy of Sciences, the Academy of Agriculture, and various higher education establishments, are also studying the problems of forestry and forest management.

The world 'forests' programme, which runs until the year 2010 , is now under way in the USSR. This covers the use of forest resources, reafforestation, afforestation for conservation purposes, seed breeding and genetics, and protection against forest fires, parasites, diseases, human activity, and radiation, among other issues.

\section{Ecological Abnormalities Unavoidable}

While it is impossible to prevent ecological abnormalities, much can be done towards ensuring that human activity respects the distinctive features of biological systems provided there is detailed knowledge of normal and critical states and of ways of restoring the balance. It is vital to focus attention on the causes of environmental problems.

The protection of natural ecosystems and hence of wider ecocomplexes, depends not only on human activity in a variety of sectors but also on scientific research on the various aspects of The Biosphere and its welfare. The study of forest ecosystem processes, and the drawing up of scientific recommendations on protection of the environment call, above all, for interdisciplinary and retrospective research, which is not yet sufficiently developed.

The Soviet State Committee on Forest Resources is ready to cooperate with all the organizations concerned with forestry problems at European, national, and regional, levels. In my view, we need a programme covering the whole of Europe and including, in addition to the pooling of information and collective research on forest ecosystems, practical activities aimed at developing a single system for monitoring European forest resources as part of a world-wide monitoring system. Some measures to that effect have already been introduced for such a purpose. The USSR, the United States, several European countries, Canada, China, and a number of other countries, have already embarked on an active campaign for overall monitoring of their forests.

VASSILI SOUKHIKH, Vice-President
Soviet State Committee
$\quad$ on Forest Resources
Moscow
USSR.

\title{
GEMI: Fostering Environmental Excellence by Business World-wide
}

\section{Introduction}

In the autumn of 1989 , a work-group on environmental management was formed by the Business Roundtable, a leading US industry coalition composed of more than 200 Concerned Environmental Organizations (CEOs). After examining the environmental practices and needs of its member companies, and consulting outside organizations and other corporations, the workgroup reported findings that pointed to two very real needs for business: (1) that in today's world the existence of corporate and trade association environmental policies in and of themselves is not a satisfactory response to societal demands for corporate responsibility and change, the real need being to define the management systems and behaviour which those policies represent; and (2) that business must provide leadership in defining and effecting responsible corporate and environmental management.

The work-group concluded further that tools to gauge the effectiveness of environmental performance need to be refined, that changes and evolution in domestic or international corporate behaviour are most effectively driven from inside corporations and the business and industrial community, and that a major, or anyway influential, centre of corporate leadership and thinking on the subject of environmental management could contribute significantly to a pro-active business ethic on the environment.

\section{Welcome to GEMI}

Consequently we hail the Global Environmental Management Initiative, or GEMI. Formed out of the findings of the abovementioned work-group, and representing many of the leading US corporations, GEMI is sketching a new archetype for the successful business of the future that incorporates sound environmental management at the highest levels and cooperates closely with government, environmental organizations, and concerned citizens. GEMI's distinction is that it was formed by environmental professionals within the business community according to their hands-on experience in environmental management issues and their vision of how such an organization - and how business as a whole - can work to improve corporate performance on a global scale.

Working with other global organizations such as the United Nations Environment Programme (UNEP), the International Chamber of Commerce (ICC), and the International Environmental Bureau (IEB), GEMI is contributing substantively to the development of a worldwide business ethic on environmental management and sustainable development. Of even greater importance is the fact that GEMI is coordinating environmental management thinking across the entire US industrial spectrum, with parallel business efforts around the world, as well as with academia, and involving both governmental and non-governmental organizations.

\section{Mission of the Movement}

GEMI's mission is simple: to foster environmental excellence by business world-wide. Within this major mission, the organization has five overarching goals:

- To stimulate, assemble, create, promote, and share, critical thinking on the subject of environmental management. 
- To improve the environmental performance of business world-wide through example and leadership.

- To participate with the world community to create consensus on and for a world-wide business ethic for environmental management and sustainable development.

- To enhance the dialogue between business, industry, and their interested publics.

- To create partnerships around the world that will encourage similar efforts.

GEMI is currently at work on a number of activities that are designed to help us to achieve these goals. Foremost among these activities was GEMI's sponsorship of 'Corporate Quality/Environmental Management: The First Conference', a January 1991 event in Washington, DC, that was aimed at spurring discussion and due application of Total Quality Management (TQM) principles to corporate environmental management programmes.

\section{Widening Influence Planned}

GEMI's 'Corporate Quality/Environmental Management' effort is ongoing, with the organization serving as a clearinghouse for innovative applications of TQM to environmental efforts. As part of this effort, GEMI is examining the methods by which companies measure their environmental activities, with the goal of improving the dissemination of information that is generated through routine measurement activities.

GEMI sponsored a seminar on its TQM effort on the day preceding the convening of the Second World Industry Conference on Environmental Management
(WICEM II), in Rotterdam in April 1991. GEMI was an active player in the proceedings at WICEM II, in part by assisting the International Chamber of Commerce (ICC) in fostering international cooperation. Additionally, a major focus of WICEM II was the unveiling of the 'Business Charter for Sustainable Development', a farreaching document on which GEMI has been working closely with ICC's Environment Commission and the US Council of International Business.

Among other activities, GEMI has launched a project to identify the communications needs of corporate stakeholders, and to document 'leading-edge' and successful methods by which corporations can meet those needs. 'Stakeholders' would include stockholders, investors, regulators, communities, employees, the media, and others.

Although GEMI has been in existence for barely a year, we feel we have already accomplished much. Even more importantly, we believe that GEMI is meeting a very real need to focus and support all the good things that are happening, and the good thinking that is prevailing at last, in environmental management in the United States. Most important of all should be its capability to integrate such envisioned, greatly-improved environmental management with the environmental efforts of world industry.

GEORGE D. CARPENTER, Chairman

Global Environmental Management Initiative (GEMI) 1828 L Street NW, Suite 711

Washington

DC 20036

USA.

\section{Canadian Heritage Rivers System: Programme of the Latest 5 Years}

The year 1991 promises to be another busy one for the Canadian Heritage Rivers System (CHRS), as it is expected that, during the coming months, up to four rivers will be formally designated and added to the System. Nineteen rivers (see Fig. 1) have now been

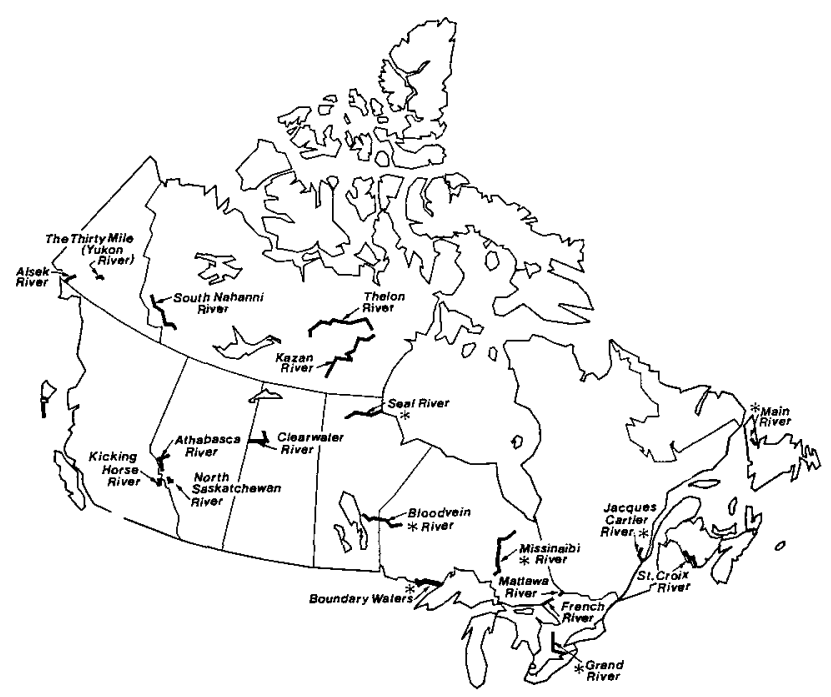

FIG. 1. Canadian Heritage Rivers System as of early 1991. Up to four additions are expected during the year. nominated to the CHRS, totalling $4,114 \mathrm{~km}$ in length, and 13 of these, totalling $2,597 \mathrm{~km}$, have now been designated.

This summer, plaque unveiling ceremonies to commemorate the designation of the St Croix River in New Brunswick, and The Thirty Mile (Yukon), are being planned.

CHRS exhibits will be highlighted during a tour of the Western provinces, and a number of studies and monitoring activities will also be undertaken, across the country, to meet the river conservation objectives of the programme. Meanwhile a 1992 Heritage Rivers calendar is being produced in conjunction with the Canadian Recreational Canoeing Association.

It is interesting to compare the current situation, indicated in Fig. 1, with that only 5 years ago as described and figured in Environmental Conservation, Vol. 13, No. 4, pp. 367-8 with map, 1986.

For further information, questions, or comments, about the CHRS, please contact Donald Gibson, the Assistant Secretary to the Board, at the address given below, or telephone (819) 9942913.
Michael W. PORTER, Secretary
Canadian Heritage Rivers System 10 Wellington Street
Hull
Quebec KIA $\mathrm{OH} 3$
Canada. 